\title{
Consumption, Consumerism, and Japanese Modernity
}

\section{Citation}

Gordon, Andrew D. 2012. Consumption, consumerism, and Japanese modernity. In The Oxford Handbook of the History of Consumption, ed. Frank Trentmann, 485-504. Oxford, UK: Oxford University Press.

\section{Permanent link}

http://nrs.harvard.edu/urn-3:HUL.InstRepos:10436348

\section{Terms of Use}

This article was downloaded from Harvard University's DASH repository, and is made available under the terms and conditions applicable to Other Posted Material, as set forth at http:// nrs.harvard.edu/urn-3:HUL.InstRepos:dash.current.terms-of-use\#LAA

\section{Share Your Story}

The Harvard community has made this article openly available.

Please share how this access benefits you. Submit a story.

Accessibility 
Consumption, Consumerism, and Japanese Modernity

\author{
Andrew Gordon \\ Harvard University
}

Prepared for the

Oxford Handbook on the History of Consumption 
The experience of people in Japan offers a rich body of evidence for comparative and global study of consumption from early modern through modern times to our postmodern present. One finds ample grist for the mill of economic historians seeking to measure the extent and the shifts in consumption of all manner of goods and services. One also finds sources in abundance from the $17^{\text {th }}$ century onward speaking to the politics and culture of regulating, lamenting, and celebrating consumption. Building on early modern foundations, consumption expanded in the era of self-conscious modernization that followed the overthrow of the Tokugawa shogunate (1868) with a turn to new goods alongside more widespread use of customary ones. As this happened, attitudes in Japan evolved as part of a global dialogue on consumer life. This was not a balanced dialogue; the transformative impact on thought and behavior elsewhere of what one historian has called America's "irresistible" market empire was profound. ${ }^{1}$ But the Japanese story is not one of simple absorption or mimicry; local patterns and understandings of consumer life were not stamped uniformly from a single mold. And especially in recent decades, global trends in consumer life have in some measure been "made in Japan."

\section{Early Modern Consumption}

Decades ago, it was common both in Japan and among foreign scholars to describe the Tokugawa era (1600-1868) in bleak terms as a time of oppressive military rule, tight restrictions on social and physical mobility, and (after about 1700) a time of economic

\footnotetext{
${ }^{1}$ Victoria de Grazia, Irresistible Empire: America's Advance Through $20^{\text {th }}$ Century Europe (Cambridge, Ma.: Harvard University Press, 2005).
} 
stagnation emblematized by famine and the widespread practice of infanticide. ${ }^{2}$ Austere sumptuary laws were understood to have restricted dress, food, and other forms of consumption for farmers as well as city dwellers. ${ }^{3}$ The best of these early works acknowledged the flowering from the late $17^{\text {th }}$ century of a gaudy urban culture centered on entertainment districts whose heroes were kabuki actors and geisha and pointed out that the frequent issue of sumptuary laws is good evidence they were not followed. ${ }^{4}$ Building on such perspectives, since the 1960s, and with increased force from the $1970 \mathrm{~s}$ and 1980s, both Japanese and Western languages scholarship on what has come to be called early modern (rather than late feudal) Japan has described a world of economic vitality and growth. Even infanticide in some cases appears to have been the act not of desperate peasants but upwardly striving, relatively prosperous farmers seeking to minimize family size to protect their assets for the next generation. ${ }^{5}$

It is possible to take this line of argument too far. The fruits of the growing economy were unevenly distributed. Famines were chronic and at times devastating as late as the $19^{\text {th }}$ century; recent work suggests that infanticide took place for diverse reasons in different places. ${ }^{6}$ But the new consensus - to me a persuasive one-holds that "any search for the historical origins of the consumer in Japan must surely begin with the significant growth in the population of towns and cities that set in after the establishment

\footnotetext{
${ }^{2}$ Honjo Eijiro, Economic Theory and History of Japan in the Tokugawa Period (1943, 1965). E. H Norman, Japan's Emergence as a Modern State, ch. 2.

${ }^{3}$ Mikiso Hane, Peasants, Rebels, and Outcastes: The Underside of Modern Japan (New York: Pantheon Press, 1982) p. 7.

${ }^{4}$ Donald Shively, "Sumptuary Regulations in Status in Early Tokugawa Japan" in Harvard Journal of Asiatic Studies Volume 25 (1964-65) pp. 123-64.

${ }^{5}$ Important early works in this mode in English include Thomas C. Smith, Native Sources of Japanese Industrialization:1750-1920 (Berkeley: University of California Press, 1988) and Smith, Nakahara: Family Faring and Population in a Japanese Village, 1717-1830 (Berkeley: University of California Press, 1977) as well as Susan B. Hanley and Kozo Yamamura, Economic and Demographic Change in Preindustrial Japan, 1600-1868 (Princeton: Princeton University Press, 1977).

${ }^{6}$ Fabian Drixler, "Infanticide and Fertility in Eastern Japan: Discourse and Demography, 1660-1880," PhD dissertation, Harvard University, 2006.
} 
of the Tokugawa regime." Japan by 1800 was home to "more large cities than any other country in the world, and its urban populations had come to rely almost entirely on the market" for a vast array of manufactured or processed consumer goods. ${ }^{7}$ City-dwellers had access to large and expanding inventories of food and drink, clothing and personal adornments, and cultural products including imported books (mainly from China) and woodblock prints, as well as services ranging from teahouses and theaters to lawyers and merchant bankers. ${ }^{8}$

Many of these goods were made (and increasingly consumed) in a countryside itself becoming more productive and prosperous. Again, care must be taken not to soar to ecstatic heights of celebration at these trends; alongside wealthy farmers engaged in trade, banking and production one finds increasingly vulnerable peasants. By the early $19^{\text {th }}$ century they were more willing than ever to protest their weakness in the face of the vagaries of the market. ${ }^{9}$ But it is clear that by the $18^{\text {th }}$ century and more densely in the $19^{\text {th }}$ century, producers, sellers, and consumers were linked in networks that not only drew goods from rural centers of specialized production to distant cities (a defining feature of "proto-industrialization"), but also placed a wide range of goods in the hands of a thickening upper strata of rural society. ${ }^{10}$

\footnotetext{
${ }^{7}$ Penelope Francks, "Inconspicuous Consumption: Sake, Beer and the Birth of the Consumer in Japan," Journal of Asian Studies (February 2009) Vol 68, No. 1, p. 142. See also Francks, The Japanese Consumer: An Alternative Economic History of Modern Japan (Cambridge: Cambridge University Press, 2009) chapter 3, pp. 47-73.

${ }^{8}$ Mary Elizabeth Berry, Japan in Print: Information and Nation in the Early Modern Period (Berkeley: University of California Press, 2007). Jonathan Zwicker, Practices of the Sentimental Imagination: Melodrama, the Novel, and the Social Imaginary in Nineteenth-Century Japan (Cambridge, Ma.; Harvard University Asia Center, 2006) ch. 3.

${ }^{9}$ Stephen Vlastos Peasant Protests and Uprisings in Tokugawa Japan (Berkeley: University of California Press, 1986) on this aspect of peasant protest.

${ }^{10}$ Kären Wigen, The Making of a Japanese Periphery, 1750-1920 (Berkeley: University of California Press, 1995).
} 
One noteworthy new element in consumer life of the late Tokugawa era which supported these developments was the offer of credit for the purchase of daily life goods. In the $19^{\text {th }}$ century, indigenous providers of consumer credit were particularly prominent in the lacquer industry which developed in central and southwestern Japan, especially Ehime, Wakayama, and Kyushu. Improvising upon a traditional form of mutual credit provision called mujin or $k \bar{o}$, lacquer ware was sold to relatively well-off rural households with payment made in quarterly installments. ${ }^{11}$

It is tempting to clinch the case that Tokugawa Japan was a time of expanding consumption by offering a long list of the goods finding their way into the hands of more and more city-dwellers and country folk. Indeed, this is a favorite (and effective) tactic of historians. Susan Hanley writes that "in 1813, one shop in the village of Ōi sold ink, paper, writing brushes, pots, needles, pipes, tobacco and pouches, teapots, various containers and dishes, vinegar, soy sauce, bean paste, salt, noodles, kelp, sake, cakes, tea and teacups, senbei (rice crackers), grain, oil, candles, hair oils, hair strings and hairpins, cotton clth, towels, tabi(socks) footgear including zori, geta (wooden clogs), and waraji (straw sandals), funeral requisites, and 'other everyday necessities.",12 Such a list, it is important to note, is not only a rhetorical device of historians. Its production was itself a new and favorite cultural pastime of Japan's early modern era. The proliferation of all manner of published lists and rankings makes it clear that expanding consumption was

\footnotetext{
${ }^{11}$ See Geppu kenkyū, [Installment Studies] 1, No. 1 (April 15, 1957): 3. Mujin or ko were revolving mutual credit funds where members met monthly, usually for a meal and drinks, and each contributed an agreed sum. The total was given to the winner of a lottery. Subsequent lotteries were limited to those who had not yet won. In the Ehime lacquer innovation, all members of a group received their goods upon an initial pooled payment, and periodic subsequent payments were collected from the entire group. Tetsuo Najita, Ordinary Economies in Japan (Berkeley: University of California Press, 2009) Ch. 6, "The Mujin Company" pp. 175-209 offers an important recent discussion of the mujin.

${ }^{12}$ Susan Hanley, Everyday Things in Premodern Japan: The Hidden Legacy of Material Culture (Berkeley: University of California Press, 1997) p. 17. See also, for example, Wigen, Making, p. 64. Francks, "Inconspicuous Consumption," p. 143.
} 
beginning to produce "consumerism," understood as a self-conscious discourse which both celebrated and fretted over the increase in getting and spending. In her brilliant meditation on the proliferation of information as a defining mark of an early modern nation, Mary Elizabeth Berry introduces the genre of the "urban survey" in which such lists featured prominently. The Dappled Fabric of Edo, for example, in its summary of one avenue in the central Nihonbashi area enumerates as residents:

Lacquerers, dealers in ink and writing brushes, dealers in silk thread, booksellers, dealers in raincoats, dealers in mirrors, dealers in fans, dealers in Buddhist goods, dealers in swords, mounters and binders [of paintings and books], dealers in Buddhist robes, printers, dealers in koto, dealers in samisen, carvers of bone and horn, cake makers, dealers in mortuary tablets, dealers in paper, dealers in candles, dealers in heavy brushes, dealers in baskets, dealers in lacquer goods, and dealers in Chinese-style straw hats. ${ }^{13}$

She concludes that these surveys "took as their subject the opportunities of consumers and strangers." They were woven from a "warp of streets and wards," and a "weft of commercial enterprise, historical legacy, and ritual activity" which "traced images of ambition and power" and in which "the market rivaled the regime as a source of autonomous power." ${ }^{14}$ It would take the argument too far-and farther than Berry herself would go - to say that the market was the primary solvent which brought down the old regime. But it surely played a role in shaking its foundations. And it is certain that a robust world of consumption and a widespread apprehension of its importance were both in place well before Japan's modernizing revolution of the late $19^{\text {th }}$ century.

\footnotetext{
${ }^{13}$ Berry, Japan in Print, p. 156

${ }^{14}$ Berry, Japan in Print, p. 184.
} 


\section{The Emergence of the Modern Consumer}

Japan's modern era is conventionally dated from 1868. In this year insurgent samurai overthrew the Tokugawa regime. They installed a new emperor (Meiji) and announced the "restoration" of imperial rule. Although early changes were cloaked in ancient form, in many respects the years immediately following this event did mark a sharp break with the past. In the decade of the 1870 s, old status distinctions and privileges were abolished, including those of the samurai themselves. The 270 semiautonomous domains ruled by warrior families with hereditary claim to their positions were replaced by a much smaller number of prefectures headed by centrally-appointed governors. The new state imposed a unified national tax, a military draft and compulsory education. Knowledge from and of the West was embraced by many. In the 1880s a modern constitution modeled on that of Prussia was written and promulgated.

But consumption was one realm where the modern revolution of these two decades had little impact. Susan Hanley, in her study of everyday life in Tokugawa and Meiji Japan, makes a strong case that it was not "until the twentieth century that the elements of everyday life — the material culture — began to become significantly Westernized or modernized for most people." ${ }^{, 15}$ To be sure, even in the 1870 s leaders of the new government, followed some years later by their wives, donned Western dress in public, and the fashionable Ginza district of red brick shops (constructed in 1875) drew wide attention and was celebrated in woodblock prints. But the Ginza "Bricktown" did not emerge as a vibrant commercial district for several decades. In realms of housing, food, and dress into the 1890s, gradual improvement in standards of living mainly took

\footnotetext{
${ }^{15}$ Hanley, Everyday Things in Premodern Japan, p. 156. Francks, The Japanese Consumer presents a similar argument. See especially ch. 4, pp, 74-107.
} 
place through the more widespread consumption of traditional goods previously limited to the wealthy. These ranged from ceramic hibachi for home heating, to polished white rice (not a healthy shift) and increased use of soy sauce, to straw sandals (by those who had once gone barefoot). ${ }^{16}$ These goods were for the most part domestically produced. As in the past, they were sold in the countryside by peddlers or in the city in small shops. Against this backdrop, the turn of the twentieth century marks the advent of a modern consumer life marked, and indeed defined, by a particularly pronounced tension between discursive and social practices. Key elements of "modern" consumption included the following. It centered in cultural imagination on urban, educated, middle class families. It was typically paid for through monthly salary or wages earned outside the home. Many of its goods were branded, and they were sold in new sites, most notably department stores. They were promoted through advertising in the new media of daily newspapers and monthly magazines. The purchase of these publications was itself perhaps the single most rapidly expanding modern form of consumption in the early decades of the century. Daily readership of both Asahi and Mainichi newspapers exceeded one million by 1924 . Monthly magazines soared in popularity, with publications for women prominent among them. In the early 1920s the three most popular women's magazines (Women's World [Fujokai], The Housewife's Companion [Shufu no Tomo], and Ladies Club [Fujin Kurabu]) each claimed circulations in excess of 200,000 copies. Total monthly sales of women's magazines exceeded one million copies. The consumption practices these magazines promoted involved goods of modern (Western) industrial civilization, from toothpaste and soap to electric fans and sewing machines, although few could afford these latter. Their spread initiated an ongoing, uneasy

\footnotetext{
${ }^{16}$ Hanley, Everyday Things, pp. 156-68.
} 
negotiation between lifeways understood to be modern and Western and those presented as traditional or Japanese.

Middle class consumers were more diverse in social practice than in cultural imagination, for they included shopkeepers, wholesalers, and small-scale manufacturers, whose occupations and lives had early modern lineage. But observers identified their center of gravity as the families of wage or salary-earning office workers, and their families: government bureaucrats and low-ranked clerks, managers in private corporations and financial institutions, and lower level corporate functionaries or technicians. By the 1920 s, such people had reached a critical mass as a significant minority in the vanguard of consumer life and a wider presence in cultural imagination. Occupational surveys show a large increase in the proportion of "office staff" positions in major cities, in Tokyo, from 6 percent in 1908 to 21 percent in $1920 .^{17}$ The numbers of vocational middle schools increased substantially, and a multi-tiered system of recruitment began to link these institutions, as well as higher schools and universities, to corporate and government employers. The contestants for these jobs included not only the children of former samurai, but also the offspring of the old middle class of urban shopkeepers or manufacturers, or middling farmers in the countryside. ${ }^{18}$

As mass media and department stores dangled new goods in front of these people, commentators and participants engaged in vigorous discussion of the extent and meaning of a new consumer life. In the early 1920s, this centered on "cultural" life and "cultural homes" which housed the people and the goods of the modern middle class. Historian Jordan Sand has observed that such discourse "marked the beginning of an incessant

\footnotetext{
${ }^{17}$ Matsunari Yoshie, et. al. Nihon no sarariiman_[The Japanese Salaryman] (Tokyo: Aoki shoten, 1974) p. 31.

${ }^{18}$ Matsunari, et. al. Nihon no sarariiman, p. 35.
} 
dialectic between consumers' dreams and their frustrated reality that is itself an aspect of the modern condition." 19 The flourishing media industry offered the arena where this dialectic played out. A rich array of image and text described a gendered consuming world populated by women in a variety of roles, as well as their salary-man husbands or fathers. They partook of new services as well as goods. The first three decades of the century witnessed a dramatic proliferation of milk halls and beer halls, Western-style restaurants for a wide range of budgets, and new forms of leisure from bathing to spectator sports, most famously baseball. ${ }^{20}$ In women's magazines of these years, the housewives of the middle class could study cooking and sewing. They could learn of the latest fashions on sale for themselves or their children in the multi-story department stores recently erected in the major cities. They could read articles about how to earn money in their spare time and tales of the successes, and the tribulations, of the small but growing band of full-time working women with jobs as seamstresses or hairdressers, typists or teachers (stories of the hundreds of thousands of textile spinners were rare).

But the greatest attention was devoted to the character known as the "modern girl." She was photographed strolling on the Ginza, lampooned in cartoons, lamented or celebrated in essays of numerous social commentators, and depicted in literary masterpieces (serialized in newspapers) such as Tanizaki Junichirō's short novel Naomi. Tanizaki's heroine was a café waitress, and in his story, as in the media telling more generally, waitresses flaunted their sexuality and broke convention by choosing their own partners. The sexual services industry continued to thrive in the old setting of licensed quarters which reached back to the $17^{\text {th }}$ century, but by the end of the 1920 s café

\footnotetext{
${ }^{19}$ Jordan Sand, House and Home in Modern Japan: Architecture, Domestic Space, and Bourgeois Culture (Cambridge, Ma.: Harvard University Asia Center, 2003) p. 226.

${ }^{20}$ Francks, The Japanese Consumer pp. 112-18 for a more extensive discussion of these leisure trends.
} 
waitresses outnumbered licensed prostitutes in Tokyo, and their relative freedom was seen by some as a threat to social order. ${ }^{21}$

This world of the urban middle class was not simply a media concoction. But those who read of the lives of such people far outnumbered those who actually worked in city offices, shopped in department stores, or frolicked in cafes. Some indication of this reality gap is offered by ownership data for the treasured items of middle class life. Of the products of modern machine civilization, only the bicycle was truly an item of mass consumption by the end of the 1920s; the total number of bicycles in use in Japan rose from about 500,000 in 1910 to nearly 8 million by 1930, an impressive number in a nation of roughly 14 million households. ${ }^{22}$

Bicycles were outdoor goods, and most users in the early $20^{\text {th }}$ century were men. ${ }^{23}$ The most important industrial product making its way primarily into the hands of female consumers was the sewing machine, but the penetration rate was considerably less. Singer dominated this market and sold roughly 500,000 household machines in Japan between 1903 and 1930, establishing a foothold in actual ownership and a much larger presence in image and brand awareness. Advertising, magazine articles, word of mouth, and the ubiquitous presence of thousands of door-to-door salesman working out of a network of nearly 800 shops throughout the Japanese empire by the early 1930s made this good far better known and desired than possessed. By 1930 perhaps four percent of Japan's households owned these machines.

\footnotetext{
${ }^{21}$ On café waitresses, Miriam Silverberg, Erotic Grotesque Nonsense: The Mass Culture of Japanese Modern Times (Berkeley: University of California Press, 2006) pp. 73-107, and Sheldon Garon, Molding Japanese Minds: The State in Everyday Life (Princeton: Princeton University Press, 1997) pp. 106-111.

${ }^{22}$ Suzuki Jun, Shin gijutsu no shakai shi (Tokyo: Chūō kōron shinsha 1999) p. 205.

${ }^{23}$ In 1905 , the fact that 30 or so schoolgirls commuted to class by bicycle was sufficiently remarkable to merit newspaper coverage. Suzuki, Shin gijutsu no shakai shi p. 201.
} 
A single state administered network (NHK) began radio broadcasts in 1925, and the proportion of households owning radios by 1930 had not passed 5 percent. With the exception of electric fans and irons, none of the other goods spreading rapidly in the United States, such as refrigerators, stoves, washing machines, or phonographs, found even this level of use. Indeed, these products remained so firmly in the realm of fantasy that advertisers actually held back from promoting them. A model house on exhibit in the newly developed suburb of Denen-chōfu in 1924 featured an electric stove, washing machine, and vacuum cleaner, but the executive in charge of the exhibit is said to have removed these goods when he realized how much the electricity to run them would cost the potential homeowners. ${ }^{24}$ With or without such treasures inside, only a small minority of Japanese could afford to live in the "cultural" homes built by railway and real estate developers.

In this context, aspiring consumers spoke in frustrated, anxious terms. During World War I, Japan's European competitors temporarily disappeared leaving Japanese producers as the only suppliers for many domestic and Asian markets and sparking an unprecedented economic boom. But inflation surged together with industrial production. Newspapers published laments such as this 1918 letter from an elementary school teacher supporting a family of five. After listing monthly expenses totaling 20.75 yen, he asserts: my monthly income after deductions is 18 yen and change. Even 20 yen are not enough. How can we live on 18? There's no choice but to cut our rice costs a little by mixing in barley, more than 50 percent, and once a day making a meal of barley-rice gruel. Because charcoal is expensive, no one in the family has taken a bath for over a month, and we can hardly afford a cup of sake, or a few pieces of

\footnotetext{
${ }^{24}$ Suzuki Shin gijutsu no shakai shi p. 241
} 
meat, or even a single potato. To buy a new kimono is out of the question. Is there anything so pitiful as the life of an elementary school teacher who cannot afford to dress his child in a New Year kimono or even eat mochi ${ }^{25}$

This letter is noteworthy not only for its plaintive tone. It was published in the decidedly modern medium of the daily newspaper. It was written by a salaried man in a job - the public school teacher-itself new to the modern era. But other than meat and potatoes, the goods and practices he saw as appropriate to his status, yet cruelly out of reach, were indigenous. New was the expectation that his family eat white rice, bathe regularly at home, drink sake with dinner, and purchase new kimono for the New Year.

Despite such frustrated desires and the highly uneven spread of goods old and new, consumption did grow steadily through these decades. People generally paid for food, drink and leisure services in cash. But they increasingly bought the goods which defined the "cultural" life of modern industrial civilization with money they did not yet have in hand. In this they relied on diverse indigenous and foreign practices which emerged more or less simultaneously around the turn of the $20^{\text {th }}$ century. What defines them as modern is the fact that borrowers were required to make regular installment payments linked to the new practice of monthly salaries or weekly wages for office or factory workers.

Indigenous providers of credit in modern times had emerged out of the late Tokugawa lenders in the lacquer ware industry. From the 1880 s into the 1890 s, the more successful seller-lenders built regional networks offering a range of goods, especially

\footnotetext{
${ }^{25}$ Matsunari, et. al, Nihon no sarariiman, pp. $44-5$ cites Tokyo Asahi Shinbun Feb 17, 1918. Mochi are sticky rice cakes traditionally prepared for New Year holiday.
} 
furniture and clothing, on monthly installments. Apprentice merchants split off from their masters, but retained the signature trademark of a kanji character in a circle (maru): Marui, Maruzen, Marukyo, Marutake, Maruichi, and so forth. These businesses evolved into "installment department stores" from the late 1890s, selling household goods such as furniture, bedding, tatami, clothing (including men's Western dress), lacquer or ceramic ware, moving from the southwest toward the northeast rather gradually. The first such seller opened in Tokyo only in 1915; a number of others immediately followed. ${ }^{26}$ These businesses appear similar in customer base and products to the so-called "borax stores" which spread in the United States from the 1880s. ${ }^{27}$

Foreign corporations provided the second source of modern installment credit. Among the most important was the Tokyo office of the [London] Times, which sold the Encyclopedia Britannica in tandem with Maruzen booksellers, and the Singer Sewing Machine Company. Singer was the most significant in systematizing and spreading installment buying. In contrast to those who patronized installment department stores, Singer's clientele were middle-to-upper class urban wives and daughters. Unlike most native installment sellers, some of whom required no contract at all, Singer and the other foreign sellers used detailed signed agreements. Terms of repayment were considerably longer, and the cost of a typical good was higher. A Singer machine represented about two months' wages for an ordinary "salaryman," making a purchase "on time" the only way for many to afford it. In the 1920s, roughly two-thirds of annual sales of about 50,000 machines were sold on the installment plan. ${ }^{28}$

\footnotetext{
${ }^{26}$ Tokyo shōkō kaigisho, Geppu hanbai seido (Tokyo: Tokyo shōkō kaigisho,1929) pp. 212-213.

${ }^{27}$ Lendol Calder, Financing the American Dream (Princeton: Princeton University Press, 1999) pp. 56-57.

${ }^{28}$ Janome kabushiki kaisha, Janome mishin sôgyô 50 nenshi (1971). Kuwahara Tetsuya, "Shoki takokuseki kigyô no tainichi toshi to minzoku kigyô," Kokumin keizai zasshi 185, no. 5 (February 2002): 50.
} 
Sellers and buyers understood themselves engaged in a progressive new practice of American or British origin, something Japanese people should be proud of doing, and ashamed to fail at. A Singer leaflet from 1908 proclaimed, "Japan is the country of progress." Six years earlier, an article in the Jiji Newspaper proudly announced that Maruzen bookstore was selling the Britannica Encyclopedia for a 5 yen down payment and 10 yen monthly installments. Jiji cautioned "that the Times corporation is using this method in Japan proves that it views Japanese and British people as equal and is giving us sufficient trust. Therefore, if anyone somehow breaks the contract, this will wound the reputation of Japan and betray the hopes of the foreigners." 29

The first organization in Japan to survey this emerging world of consumer credit in systematic fashion was the Tokyo Chamber of Commerce. Its pioneering 1929 study introduced readers to credit in the United States and Britain, as well as Japan. It drew on E.R. Seligman's important and just-published opus, The Economics of Installment Selling (1927), for the account of the American scene. ${ }^{30}$ It notes that a dramatic expansion of installment selling had begun in Japan in the mid-1920s. ${ }^{31}$ One new entrant was Nihon Gakki (Yamaha), selling pianos and organs since 1924. In addition to a scattering of other household appliances sold on credit, suburban homes were sold on several-year mortgages along the newly opened commuter railway lines.

Although installment selling was both an imported American practice and a modernized form of an indigenous practice, and was sometimes recognized as both, the imported practice drew more attention. An academic article from 1933 based on a survey of 254 installment sellers in Osaka and Tokyo claims the salaried urban life "perfected"

\footnotetext{
${ }^{29}$ Cited by Fukushima Hachirō, in Gekkan Kurejitto, No. 200 (1973), p. 20.

${ }^{30}$ On Seligman, see Calder, Financing the American Dream, pp. 237-248.

${ }^{31}$ Tokyo shōkō kaigisho, Geppu hanbai seido (1929) p. 227.
} 
in the mid-1920s was a "cultured life" centered on "so-called "American goods" such as sewing machines and pianos. ${ }^{32}$ By 1934 , according to another survey, conducted by the city of Tokyo, roughly 10,000 of 130,000 retailers in greater Tokyo offered their goods on time. Eight percent of all Tokyo retail sales were estimated to be made through installment plans, said to be a remarkably high number for a new practice. ${ }^{33}$ The top goods sold on credit were men's Western dress, bicycles, automobiles, shoes, radios, sewing machines, books, medical and scientific equipment (including cameras), watches and jewelry, and Western furniture. Clearly the link between consumer credit and a new consumer life tied to goods of Euro-American origin was intimate. Almost all the items on this list were products of Western material and for the most part industrial civilization.

Through the 1930s (and beyond), both in goods consumed and in the use of credit to buy them, Japan was certainly playing catch up to the global leaders, beginning with the United States. But as the almost immediate appropriation of Seligman's work on credit suggests, people in Japan took part more fully in the self-consciousness of modern consumerism than in the socio-economic practice of modern consumption. The effort to study these transformations of daily life proceeded in near simultaneity with similar assessments in the consumer societies of the West.

The Tokyo Chamber of Commerce was among the most noteworthy in its prescient perspective. The preface to its 1929 report states that:

\footnotetext{
32 Hirai Yasutaro "Honpō ni okeru bunkatsu barai seido no genjō ni oite," Kokumin keizai zasshi 43, no 2 (1933):69-73, 81.

${ }^{33}$ Tokyo shiyakusho, kōgyōkyoku, shōgyōka, Wappu hanbai ni kan suru chōsa (March 1935).
} 
To recover from the long recession... along with urging the rationalization of management....it is necessary to reform the consumer economy, increase the efficiency of consumption, eliminate waste, lower the expense of daily life, and thus rationalize daily life....The skillful operation of this [installment credit] system can make a major contribution to rationalization of both management and daily life. From the perspective of the consumer, installment purchases allow one to buy goods of considerable cost, which is far more economical [in the long run] than purchase of inexpensive shoddy goods with cash....this allows one to level out expenditures over time. It is not only extremely useful in order to lead a disciplined life, planning a monthly budget of expenses; it also raises standards of living by allowing purchase of goods otherwise too expensive."”34 Most striking in this passage is the appreciation of installment credit as a form of social discipline not unlike investment or savings. Although Seligman in his classic 1927 defense of consumer credit recognized the disciplining function of installment credit, he was less explicit than these Tokyo authors in stressing its centrality. ${ }^{35}$ The Chamber of Commerce authors find it a strange fact that in the land of the most developed market for installment purchase, there seems to be more opposition than support. ${ }^{36}$ By the late 1920s, Japanese observers were in the forefront of global trends in their insights on the significance of American-style installment selling.

Opinions on the disciplining effects of consumer borrowing also included contrary voices worried that installment credit might fray the social fabric, make buying too easy, and over-extend a consumer beyond the ability to pay. As a rhetoric extolling

${ }^{34}$ Tokyo shōkō kaigisho, Geppu hanbai seido pp. 1-2.

${ }_{35}$ Calder, Financing the American Dream, pp. 29-33.

${ }^{36}$ Tokyo shōkō kaigisho Geppu hanbai seido, pp. 181-188. 
traditional values gained force along the road to war, one outraged marketing expert wrote in 1938 that "the American-style system of installment selling is extremely cruel and completely at odds with the spirit of the Japanese nation and the virtue of Japanese people." $" 37$

While debate over credit constituted one stream of the modern discourse of consumer life, another more pervasive flow of words swirled around the effort in a context of rapid change to define or defend a particular Japanese identity in daily life and consumer choices. Discussion was most often directed at the threat or promise of what came to be called the "two-layered life" (ni-jū seikatsu, also translatable as "double life"). The term refers to the simultaneous presence of goods and practices described as "Western" and "Japanese" in realms of food, housing, and dress. Newspapers, magazines — especially those for women — and more academic publications for professionals in fields such as architecture and home economics were full of anxious discussion of the pros and cons of practices such as tatami-sitting versus use of chairs or the merits of Japanese kimono versus Western dress.

The Japanese state played an important part in framing this discussion of the "two-layered" life and daily life more generally. In the immediate aftermath of World War I, as the state significantly broadened its efforts to reinforce order in a complex, contentious society, bureaucrats allied themselves with middle-class reformers and experts in various fields. Officials in the Home Ministry and the Ministry of Education played the key role in founding one such initiative in 1919, the League to Reform Everyday Life. Over the following years, in publications, exhibitions, and lectures, the League connected state officials with outside experts and activists. Attentive to each

\footnotetext{
${ }^{37}$ Matsumiya Saburo, Sugu kiku kōkoku (Tokyo: Mikasa shobō, 1938) pp. 77-80.
} 
other and to the work of counterparts in Europe and North America in fields ranging from architecture to home economics, they organized more narrowly focused committees concerned with rational and scientific housing, food, and clothing. ${ }^{38}$

The Japan Dress Reform Association was one such organization. Founded in 1921, the Association sought to relieve the burden of the "two-layered" life by designing reformed versions of Western-style dress which better fit Japanese bodies. To this end, it published a book written by two of its leading members, the husband and wife team of Ozaki Yoshitarō and Gen. The work, itself, was a consumer good of sorts. Titled Economic Reform: Sewing for the Future, this nearly 500 page tome sold 70,000 copies. It argued that for reformed dress to prevail, it had to be simple enough to fabricate in the home, with or without a sewing machine, and it had to be economic in its use of fabric. It also had to allow free and active movement. ${ }^{39}$

Hata Rimuko, head of the Singer Sewing Academy, founded by the company to educate both customers and its own cadres of teachers, picked up the thread of this concern in the 1924 preface to the second edition of her best-selling sewing textbook:

Recently, the numbers of women and children wearing western clothes has increased greatly. This appears at first to be a welcome trend, but if this is simply a matter of pursuing fashion with no sense of principle, it is most regrettable. The burden placed on the nation by the spread to women of the two-layered life in clothing is fearful even to think about. ${ }^{40}$

\footnotetext{
${ }^{38}$ On these campaigns more generally, Garon, Molding Japanese Minds, pp. 10-15. On the League's efforts in housing reform, Sand, House and Home in Modern Japan, pp. 16-19, 181-202.

${ }^{39}$ Inoue Masato, Yofuku to Nihonjin: kokumin fuku to iu moodo (Tokyo: Kōsaidō shuppan, 2001), pp.14345, 221. The Japanese name for the dress reform organization is Nihon fukusō kaizen kai.

${ }^{40}$ Hata Rimuko, Mishin saihō hitori manabi (Tokyo: 1933). 3rd ed., pp. 3-4 reprints preface to second edition.
} 
She continued by noting that the "double life" burden could be solved "if it were possible to simply cease making Japanese dress," but she has to admit "far into the future, women are not going to abandon Japanese dress." Given this situation, she offered some options to ease the economic and decision-making burden of the double life in dress: limit Japanese wear to ceremonial occasions; only gradually move from Western dress for work to Western dress for social events; or adopt those Western fashions such as the "one piece" dress which are similar in fit to Japanese clothing and relatively easy to sew. Hata was well aware that Western dress was more amenable to sewing by machine than Japanese dress, or at least that users believed this to be true. Her interest as head of the Singer Sewing Academy was unambiguous: the more quickly women moved to Western dress, the better. Her remarkably cautious and defensive advocacy of Western dress despite her self interest makes clear that dress for female consumers carried a particular burden of defining cultural identity in a changing world.

Hata's dilemma continued to surface in debates concerning the pros and cons of hand versus machine sewing and the merits of Japanese versus Western dress. As such debate took place with growing frequency in the 1920s, some of Japan's best-known writers, such as Tanizaki Junichirō, were writing with elegant nostalgia about what they saw as a sad disappearance of traditional lifeways in the face of the uncritical embrace of the modern and the Western. ${ }^{41}$ Such writing rested on a commonsense binary opposition that in Hata's case set Japanese sewing, hand stitching, kimono dress, and "tradition" against Western sewing, sewing machines and machine stitching, Western dress, and "modernity." But here and in debates over daily life reform more generally, it is

\footnotetext{
${ }^{41}$ Works by Tanizaki that evoke this spirit include Some Prefer Nettles, first published in Japanese in 1928 and In Praise of Shadows first published in Japanese in 1933.
} 
misleading to map the struggle as a fight between "Japanese" tradition and "Western" modernity. Each party to this debate was making a claim for the consumer practices best suited to its particular understanding of a life that was both "Japanese" and modern, one which accepted and often embraced values of rationality, speed and efficiency, and sometimes freedom of choice even as it celebrated Japanese-ness.

The modern discourse of the consumer in Japan was complex not only because those who defended traditional patterns of consumption in this way argued their case on modern grounds. Another significant and enduring complexity of the interwar discourse of consumption is that some understood the modern consumer as a disciplined subject of the modern nation, others saw her as a legitimate seeker of personal fulfillment and pleasure, and some saw her as both. Consider, for example, a 1936 newspaper advertisement placed by a domestic producer of sewing machines seeking to compete with Singer. Next to the profile of an elegant Caucasian-appearing woman, the ad copy reads: "You! This year's resolution is to earn a ton with your woman's hand! It's shop 'til you drop, as fast as you can." The lengthy text goes on to explain that "the American woman is the one who plays more, buys more, and earns more than any in the world. In our country as well, in 1936, one new trend for women is to earn without hesitation, and to quickly buy whatever you like without holding back." However, the reader is asked, how on earth can a woman with obligations to do so much housework find time to earn and then to spend money? The answer is simple: "the problem is solved perfectly by bringing in science." If one buys a scientific product such as sewing machine, one can economize on time and expenses and use the profit to shop to one's heart content. ${ }^{42}$ The

${ }^{42}$ Asahi Shinbun, 9 January 1936: 5. 
ad thus brilliantly juxtaposed the scientific, frugal, and rational aspect of modernity with the face of the pleasure-seeking consumer, and it validated both aspects.

\section{The Consumer and Wartime Modernity}

Such newspapers already blanketed the nation by the end of the 1920s. Over the next decade the level of media saturation increased sharply due to a combination of new technology, increased prosperity and purchasing power, and the collaborative effort of state and private actors to mobilize for war and chronicle its progress. In a bit more than a decade the newest mass medium, radio, soared in popularity. Subscriber households rose by a tenfold, from 650,000 in 1929 to 6.6 million by 1941 . The number continued to climb through the Pacific War, reaching a peak of 7.5 million in 1944. Geographies of region and of class changed as a result. In the late 1920s, listening to the radio at home was the privilege of the urban middle class. Even at the end of the war, as photographs and accounts of groups listening to the Emperor's surrender broadcast attest, listening to the radio was sometimes a communal activity, especially in the countryside. But over the course of the 1930s, radio came to cast a far wider net. In the early 1930s, roughly one in four urban households subscribed to NHK radio broadcasts, but only one in twenty rural homes did so. By early 1940 radio use in the cities had doubled, but use in the countryside rose fourfold; NHK's "Radio Yearbook" for 1940 reports that one in five rural households were subscribers. ${ }^{43}$ The radio was both the most widely owned electric good for use inside the home, and a primary means to bring additional information and

\footnotetext{
${ }^{43}$ Nihon hōsō kyōkai, Rajio nenkan (Tokyo: Nihon hōsō kyōkai, 1940) p. 270.
} 
dreams, whether of economy, empire and conquest, of education and culture, or of sports and amusement, into the lives of millions of people.

The surge in radio subscriptions resulted in significant part from intense media competition to cover and to glorify Japan's new imperialism of the 1930s. Sparked especially by the Manchurian Incident in September of 1931, newspapers such as Asahi and Mainichi competed with each other, and with NHK, to be first with the top stories of the day; they turned to airplanes to send reporters and film to and from the continent, and they turned to newsreels and movie theaters as well as newsprint to reach a fast-growing mass audience. Spurred by the advent of talkies, movie audiences nearly tripled in size in the decade from 1930, surpassing 400 million viewers at 2,363 theaters by 1940, an average of nearly 6 films per year per person. In sum, as historian Louise Young concludes, the Manchurian Incident sparked a dramatic "growth spurt" for an already strong news industry, a "process of innovation and expansion in the mass production of an industrialized mass culture.",44

War and entertainment co-existed throughout the decade, and despite rising political tensions between the United States and Japan, the American origin of so much of mass cultural production did not impede its enjoyment. Charlie Chaplin's May 1932 visit to Japan was the focus of huge popular interest, even though it coincided with the assassination of Prime Minister Inukai. Japan's first professional baseball teams began to compete regularly in 1934. That same year, thousands of people thronged to see Babe Ruth play with an American team in 18 exhibition games in 12 major cities during a

\footnotetext{
${ }^{44}$ Louise Young, Japan's Total Empire: Manchuria and the Culture of Wartime Imperialism (Berkeley: University of California Press, 1998) p. 68.
} 
month-long tour. A capacity crowd of 65,000 jammed the stadium in Tokyo for the first game. Pro baseball continued to be played until November 1944.

The frequent convening of such commercial public spectacles coincided with the proliferation of new forms of retail shopping and new services and habits of personal decoration, especially for women, part of a quickly changing urban landscape centered on the modern middle-class consumer. Hair salons spread throughout Japanese cities in the 1930s, offering permanents to thousands of middle-class women. By 1939 there were about 850 such hair salons in Tokyo alone. Sewing schools and dress shops likewise expanded in popularity more rapidly in the 1930s than before. By 1943, at the height of the war, no less than 1282 dress shops (572 owned or operated by women) were in business in Tokyo alone. ${ }^{45}$ In tandem with these trends, the sales and ownership rates of sewing machines spiked upward sharply in the 1930s, with the greatest increase in fact coming between 1935 and 1940. By the eve of the Pacific War, nearly one in ten Japanese households owned a sewing machine.

Of great fascination for male media and culture critics, as well of course for women themselves, both on grounds of fashion and of purported rationality the 1930s saw a significant acceleration of a shift toward women's Western dress. It was said to be more efficient for factory workers, safer for evacuation in case of earthquake or fire, and more comfortable for all manner of daily activity.

In sum, although a wide gap remained between the modern consumer life as dream and as materially-owned reality, across the 1930s it began to close; a significantly expanded proportion of people in Japan, especially in the cities, came to possess the objects that defined middle-class modernity. An even greater proportion joined modern

${ }^{45}$ Nakayama Chiyo, Nihon fujin yōsō shi (Tokyo: Yoshikawa kōbunkan, 1987) pp. 411-25. 
life simply by strolling along city streets, reading monthly magazines, going to the movies, or listening to radio broadcasts ranging from English or sewing lessons to Olympic sports. At the very least, this expansion of the realm of material and cultural modernity took place in spite of the drift toward war; one sees a persistent rise in consumption and continued attraction to a life of modern mass leisure despite the increasingly censorious demands of the wartime political leaders that people offer patriotic service in a time of emergency, live more simply and reject American ways.

Ironically however, this modern life of consuming and leisure also spread because of the efforts to cope with depression and war. First, and most obviously, after the Manchurian Incident the economy recovered smartly from the depression sparked in part by war-induced deficit spending, giving more people the means to buy consumer goods and take part in modern leisure activities. Second, as both state and commercial media beat the drums for war modern media spread their reach ever further. Third, the logic of "rationalization" first articulated during the recession and depression from the late 1920s included calls not only for streamlining and frugality, but also injunctions to modernize material life including wartime dress for both men and women.

With luxury the enemy and Hollywood the ever-tempting dream, the desires of the modern consumer thus persisted into the dark heart of wartime. But with the year 1939 one turning point, and 1942-43 a more decisive break, the combination of increasingly stringent economic policies and a growing scarcity of resources came to limit the ability of women and men to pursue their modern pleasures. In an effort to hold down inflation and protect the purchasing power of a labor force mobilized for war, the government imposed price and wage controls in 1939 and put in place rules limiting the 
free movement of workers. These policies, designed to end the "wasteful" competition of a market economy and funnel capital and raw materials to military production, made it increasingly difficult to manufacture and sell consumer goods. By 1944-45, a home front nightmare of scarcity, rationing, and fire-bombing turned the story of consumption into a desperate tale of struggles to survive.

Yet, to present consumption in Japan after Pearl Harbor as a linear narrative of the inexorable constriction fails to capture the complexity of negotiations to control tastes across realms from music to hair styles to dress which continued at least until 1944, and it misunderstands their outcome. In Blue Nippon, E. Taylor Atkins argues that the persistence of jazz in wartime Japan sparked relatively creative efforts, however riddled with contradiction, to devise an "authentic" Japanese jazz. ${ }^{46}$ Echoing the improvisations of jazz, those who designed clothes, taught sewing, or used sewing machines took part in a tortured wartime effort to design an "authentically" Japanese but functionally modern dress, dubbed "people's dress" in the case of men and "standard dress" for women. ${ }^{47}$ These efforts to define a "Japanese" daily life in a time of total war, one can say—at some risk of giving insufficient weight to its ultimate horror-were ironically productive. Amid a flood of rhetoric that condemned the modern and the West for corrupting the purity of the Japanese nation and soul, people were searching not so much for a traditional essence as for an "appropriately Japanese" modernity.

\footnotetext{
${ }^{46}$ E. Taylor Atkins, Blue Nippon: Authenticating Jazz in Japan (Durham: Duke University Press, 2001) pp. $127-63$

${ }^{47}$ Andrew Gordon, Fabricating Consumers: The Sewing Machine in Modern Japan (Berkeley: University of California Press, 2011), chapter 5. Inoue Masato, Yōfuku to Nihonji: kokuminfuku to iu moodo (Tokyo: Kōsaidō, 2001).
} 


\section{The Postwar Ascendance of Consumers}

The more recent history of consumption in Japan marks a quantitative break with the past in that levels of consumption soared from the 1950s through the 1990s. But in terms of the actors and their behavior, the goods desired, and the way they were discussed, the postwar story does not so much break with the past as build upon it. Mass media had been central to the promotion of interwar and wartime modernity, and the first surge in the postwar return to a "normal" daily life of modern goods and pleasures came in the production of texts, voices, and moving images. A voracious public consumed all manner of books, magazines, radio broadcasts and movies, ranging from the so-called "dregs literature" obsessed with the erotic, to political satire and analysis, to English conversation manuals and programs. ${ }^{48}$

For several years thereafter, shortages and rationing inhibited the purchase of the material goods of modern life, but as soon as the means were at hand, renewed growth in consumption further narrowed the gap between the dream of modern life and its material attainment. The new element here was not the particular goods desired, but the fact that these so increasingly — and famously — came to be made in Japan, not only for domestic use but for export. This process began in the years of American occupation with the continued "mechanization" of the household, a trend that began in the prewar decades, predating the more famous era of "household electrification." One important good in this process was the sewing machine; it allowed buyers, including thousands of war widows, to earn money as seamstresses or home-workers, even as it was marketed as a scientific

\footnotetext{
48 John Dower, Embracing Defeat: Japan in the Wake of World War II (New York: Norton, 1999), Part II (chs. 3-5) superbly evokes this cultural efflorescence.
} 
object of high technology or as a glamorous, even sexy, symbol of a bright new modern life. In 1951 Japanese makers were selling over one million household machines per year, about two-thirds for export; by 1952 domestic sales topped 500,000 machines. ${ }^{49}$ Then, from the mid-1950s, as a government White Paper famously declared "the postwar era is over," the electrification of Japanese households began in earnest. According to one survey, by 1960 the proportion of Japan's 20 million households owning key household consumer goods stood as follows: radios, 89 percent; sewing machines, 72 percent; bicycles, 66 percent; televisions, 54 percent; cameras, 47 percent; electric washing machines, 45 percent; electric fans, 42 percent; electric rice cookers, 38 percent; transistor radio, 25 percent; electric phonographs, 20 percent; electric refrigerators, 16 percent, and motorbikes, 12 percent. ${ }^{50}$

This nearly vertical take-off of the consumer economy was fueled by credit. Beginning in 1948 and 1949, manufacturers of bicycles, radios, and sewing machines once again began to offer their goods on the installment plan. In an important postwar innovation, which anticipated the credit cards of several decades later, newly founded finance companies offered credit tickets to consumers, usually through their employers. A consumer/employee would use the tickets, denominated like paper currency, to purchase goods at participating stores. The store redeemed the ticket for cash with the issuing lender. The lender then collected the face value plus interest in monthly installments from the consumer. This system offered flexible installment credit to buy all

\footnotetext{
${ }^{49}$ Tsūsho sangyō shō, ed., Nihon bōeki no genjō (Tokyo: Tsūsho sangyō chōsakai, 1954) p. 59.

${ }^{50}$ Nihon mishin kyōkai, ed. Nihon mishin sangyō shi (Tokyo: Nihon mishin kyōkai, 1961) p. 7.
} 
sorts of goods and even services such as movie tickets. It proved extremely popular. ${ }^{51}$ By the end of the decade, purchasing by installment was the method of choice for consumers seeking the "cultural" goods that defined the bright new life of peacetime and prosperity. Their collective shopping binge transformed radios and sewing machines, then washing machines, televisions, refrigerators, vacuum cleaners, cameras, motorbikes and (later) automobiles from luxuries to virtual necessities of the burgeoning middleclass masses.

Although they sometimes feared that excessive consumption would spark dangerous inflation or erode social discipline, observers at the time echoed and drew upon the precocious appreciation of consumer credit found in prewar discourse. They noted that such credit fueled demand and served as an engine of the national economy by connecting manufacturers, lenders, and consumers in a virtuous circle of growth. As early as 1952, the economist Kawauchi Mamoru praised installment selling for "bringing latent demand to the surface" and bringing "planning into daily life and regulating consumption."52 The Tokyo Chamber of Commerce echoed Kawauchi as well as its own rhetoric of the late 1920s in a publication of 1957, neatly encapsulating the "Fordist" logic of consumer society and political economy consolidated across the transwar era:

The installment sales system helps first of all manufacturers, but also retailers, to expand commodity markets. It plays an extremely significant role in sales strategies to insure stable sales volumes. In addition, of course it brings the benefit of raising the standard of living to consumers and rationalizes consumer

\footnotetext{
${ }^{51}$ Andrew Gordon, "From Sewing Machines to Credit Cards: Consumer Credit in Modern Japan" in Sheldon Garon and Patricia MacLachlan eds. The Ambivalent Consumer: Questioning Consumption in East Asia and the West (Ithaca: Cornell University Press, 2006) pp. 147-62.

${ }^{52}$ Kawauchi Mamoru, "Geppu hanbai no keizaigaku” Nihon mishin Taimusu, (3/ 21/ 1952) No. 172 , p. 9.
} 
outlays. It is not only the installment purchaser who enjoys the benefit of the practice. Even the cash purchaser benefits from the cost savings enabled by mass production..$^{53}$

As such claims linked borrowing to social discipline and investment as well as to economic growth they held much in common with the logic of savings promotion which was powerfully articulated in Japan during these same years. That is, postwar citizens were urged to save as a cornerstone of a responsible and disciplined economic life that would benefit producers by providing needed investment capital, but would also benefit individuals and families by providing the wherewithal for future consumption. ${ }^{54}$

Once the basics of the bright new life were widely possessed, Japan's consumer society arguably entered a new stage, what the sociologist Yoshimi Shunya has labeled the "post-postwar" era. ${ }^{55}$ He identifies the decade from the early 1970s into the 1980 s as the transition point. Globally and in Japan consumer life first came to be marked by a new degree of segmentation into various niches of consumption, and more recently has been characterized by the rise of "virtual" consumption of culture through new information technologies. As with consumer goods of the high growth postwar era, key products in "post-postwar" times, not only hardware but software such as computer games or cell phone novels, were made in Japan and circulated globally. This process reflected a growing local creativity. High growth era exports by companies such as SONY and Honda, that is, were innovative in quality and in design, but radios and cars

\footnotetext{
${ }^{53}$ Tokyo shōkō kaigisho, Wappu hanbai ni kan suru jittai chōsa (Tokyo: 1957, Tokyo shōkō kaigisho) p. 1.

${ }_{55}^{54}$ Garon, "Keep on Saving" (forthcoming) - if possible get precise reference.

${ }^{55}$ Yoshimi Shunya, Posuto sengo shakai (Tokyo: Iwanami shoten, 2009).
} 
had already been invented and developed in the West. In the post-postwar era, Japan began to produce and export cultural goods of local conception, from Hello Kitty paraphernalia and transformer toys to manga to anime. These goods constituted what the journalist Douglas McGray dubbed “Japan's Gross National Cool” in a well-known essay in $2001 .^{56}$ Their popularity continued throughout the first decade of the new century.

For McGray—who drew on Joseph Nye's analysis of the cultural dimension of national strength—-these cultural productions constituted "a vast reserve of potential soft power." That contention is difficult to assess. But the circulation of consumer entertainment from and into Japan in recent years has surely played some part in connecting cultural worlds among people in Asia as well as outside it. Millions of young Koreans have come to enjoy Japanese popular music. Millions of Japanese women have thrilled to the exploits of the dashing young Bae Yong Joon, nicknamed Yon-sama, the star of a Korean television drama, Winter Sonata. Bae was at the forefront of the "Korean Wave" of the late 1990s, referring to the growing popularity of Korean popular culture in China, Japan and Southeast Asia as well.

The irony is that this surge in new forms of cultural production and consumption has coincided not only with two decades of relative economic stagnation in Japan, but also with a leveling off in the purchase of "traditional" modern goods. Most notably, both domestic consumption and perhaps most significantly the expressed desire for owning automobiles among young Japanese consumers declined substantially in the first decade of the $21^{\text {st }}$ century. ${ }^{57}$ This trend is perhaps as good a marker as any of a world of post-modern consumer life.

\footnotetext{
${ }^{56}$ Douglas McGray, “Japan’s Gross National Cool” in Foreign Policy (May-June, 2001) pp. 44-54.

57،"Atama itai kuruma banare” Asahi Shinbun July 28, 2008 p. 3.
} 
In writing this essay, I have relied on works in Japanese as well as a number of excellent recent works in English, noted in the bibliography and for the most part written in the past decade. The appearance of this work indicates a healthy interest in the history of consumption and consumerism in Japan, but there is certainly room for additional work. One fruitful avenue is the study of particular goods - the ways they were sold, the uses to which they were put, the meanings ascribed to them. Items that would repay careful attention include bicycles, radios and pianos, as well as more personal items linked to changing bodily practices such as bath-tubs and high-tech toilets. ${ }^{58}$ Another issue deserving more systematic attention is the spatial configuration of consumption in modern Japan, both regionally — with attention to provincial cities and towns as well as to rural areas - and across the colonial empire. Finally, although the fact that postwar Japan was marked simultaneously by extremely high rates of saving, and consistent expansion of domestic consumption has been noted by economic historians, the cultural meaning of this conjuncture has yet to be fully explored. ${ }^{59}$ The Japanese case of avid spending alongside devoted saving offers fertile ground for exploring the process by which modern citizens or subjects are not so much liberated as they are disciplined by their consumption practices.

\footnotetext{
${ }^{58}$ Scholars in Japan have undertaken some impressive efforts already. One pioneering work is Amano Masako and Sakurai Atsushi, "Mono to onna” no sengoshi: shintaisei, kateisei, shakaisei o juku ni (Tokyo: Yūshindō, 1992).

${ }^{59}$ For the economic data, Charles Horioka, "Consuming and Saving," in Gordon, ed. Postwar Japan as History (Berkeley: University of California Press, 1993) pp. 259-92.
} 